A look at the region

\title{
Archaeobotany and the Terramara Archaeological Park of Montale (Emilia-Romagna, Northern Italy): Experiences of Public Education
}

\author{
Giovanna Bosia ${ }^{a}$, Giovanna Barbieria ${ }^{\mathrm{a}}$, Assunta Florenzano ${ }^{\mathrm{a}}$, Elisa Fraulini ${ }^{\mathrm{b}}$, Maria Chiara Montecchi ${ }^{\mathrm{a}}$, \\ Alessia Pelillo ${ }^{\mathrm{b}}$, Elena Righi ${ }^{\mathrm{b}}$, Rossella Rinaldi ${ }^{*}{ }^{*}$, Cristiana Zanasi $^{\mathrm{b}}$ \\ ${ }^{a}$ Laboratory of Palynology and Palaeobotany, Department of the Life Sciences, University of Modena and Reggio Emilia, Italy \\ ${ }^{b}$ Archaeological Park and Open Air Museum of Terramara in Montale, Archaeological and Ethnological Comunal Museum, Modena, Italy
}

\section{A RTICLE INFO}

\section{Article history:}

Received: $2^{\text {nd }}$ August 2017

Accepted: $21^{\text {st }}$ December 2017

DOI: http://dx.doi.org/ 10.24916/iansa.2017.2.6

Key words:

Bronze Age

environmental reconstruction

paleoethnobotany

experimental archaeology

education

\begin{abstract}
$A B S T R A C T$
The Terramara Archaeological Park of Montale is an open-air museum dedicated to the enhancement of the Bronze Age terramare culture of Northern Italy. Investigation of its rich archaeological record, particularly from the archaeobotanical point of view (seeds/fruits, pieces of wood and charcoal, pollen and charcoal particles), has made it possible to reconstruct the landscape's evolution and human-plantanimal relationships. This paper aims to present a comprehensive and exhaustive overview of the relationship between archaeology and archaeobotany in order to improve the content and exposition of the Terramara Archaeological Park of Montale, thanks to the fruitful cooperation between the Laboratory of Palynology and Archaeobotany of the University of Modena and Reggio Emilia and Civic Museum of Archaeology and Ethnology of Modena.
\end{abstract}

\section{Introduction}

For many years, numerous questions have been raised regarding archaeological site management and the preservation of its surroundings, especially for sites included in extremely anthropized contexts (Urtane 2000).

Widespread around the world and with almost a century of experience behind them, archaeological open-air museums $(\mathrm{AOAM})^{1}$ are one of the most effective ways of bringing archaeology to the public (Pelillo 2009), representing as they do human-nature interactions. They are in fact a favoured scenario for holistically combining all parties to reconstruct the complex history of humankind and nature.

Archaeological parks have a definitive value as public education tools, providing for most people the only firsthand experience at a site. Archaeologists, therefore, should pay particular attention to their management needs and educational topics - in order to provide correct and efficient

\footnotetext{
${ }^{1}$ Archaeological Open-Air Museums: the definition of AOAM refers to the Guide to the Archaeological Open-Air museums in Europe (Pelillo 2009).

*Corresponding author. E-mail: rossella.rinaldi@unimore.it
}

information about archaeology (Hoffman et al. 2002). In its dual role as an archaeological reserve and interpretation centre, a historical site or park should offer a useful mixture of research and conservation, education and leisure. Moreover, it should aspire to preserve the archaeological remains in ways that are well integrated in the surrounding landscape (Panosa 2012).

According to the Italian legislation (D.M. of $18^{\text {th }}$ April 2012), an archaeological park is a "territorial scope characterized by peculiar pieces of archaeological evidence and an overlapping of historical, landscape or environmental values, equipped as an open-air museum on the basis of a specific legislation. Archaeological parks fall under the category of territorial parks, intended as places where the mix of culture and nature is presented in different forms, sometimes with prevailing natural (geological, vegetational, faunal, etc.) features, sometimes with the historical ones (landscape, architecture, urban, mining, etc.) An archaeological park occurs when the historicalarchaeological component is quantitatively or qualitatively a key determinant."

Archaeological sites or parks contribute to the cultural identity of their own community, along with tourism 
development and the economic improvement of the territory.

Consequently, for an efficient archaeological or historical site recovery it is essential to plan a well-defined project that shall take into account its own specific features. First of all, in a revaluation project, symbolic or cultural characteristics of the site should be assessed. Archaeological or scientific features have also to be considered, according to their important contribution in terms of knowledge and awareness. Finally, careful consideration should be given to the teaching possibilities, as these represent the strongest link between the archaeological remains and the visitors (Panosa 2012).

AOAMs play a unique role in this field. Developed first in Germany and Scandinavia, while yet being relatively recent in Italy, they offer an exciting interface between scientific research and education, bridging the gap between academia and the public. By reconstructing the environments and activities of the past in a striking and evocative way, they manage to convey to a wider audience the results of excavation and research. For many of the AOAMs, a key factor has doubtless been their relationship with experimental archaeology, this developing scientific discipline having found fertile ground for testing its procedure and methods according to scientific analysis in this kind of museum, increasing the relationship between research and divulgation (Zanasi 2014a; Zanasi 2015).

In addition, there is a growing demand by the public and by schools for a form of archaeology-tourism that is increasingly taking the form of edutainment. Here the learning-by-doing philosophy evinces the visitors' emotional involvement: they are transported backwards in time, where they are immersed in the atmosphere of bygone ages. Not infrequently, this process is facilitated by the presence of qualified staff dressed in period costume and skilled in historical re-enactment (Zanasi 2014a; Zanasi 2015).

Through a hands-on experiential approach, archaeological parks are one of the best tools for humanities and science education in the cultural and environmental heritage field. According to Dyer (2007), "There are curricula across all sectors which now contain more elements of cultural heritage, ecology and sustainability - particularly in science, geography, citizenship and religious education - but somehow the holistic energy that turns facts into feelings, professional development into corporate responsibility and understanding into personal action is not there in sufficient strength. (...) Bringing concrete understanding to abstract scientific concepts through memorable experiences in an inspiring environment is a very powerful educative tool which too few programmes achieve".

\section{The Terramara Archaeological Park of Montale}

The Archaeological Park and Open-Air Museum of the Terramara of Montale, located $11 \mathrm{~km}$ from the city centre of Modena (Figure 1a), was set up in 2004 by the Civic Museum of Archaeology and Ethnology of Modena. The Terramara Archaeological Park of Montale is dedicated to the enhancement of the terramare communities and their characteristic villages in the Po plain area $\left(2^{\text {nd }}\right.$ millennium $\mathrm{BC}$, Northern Italy) that represent one of the most important and meaningful cultural entities of European prehistory (Bernabò Brea et al. 1997).

The realization of the Park was the achievement of a long period of scientific research, which had already begun earlier and is still ongoing. At the base of the enduring success of the Park there is this peculiar, constant and osmotic relationship

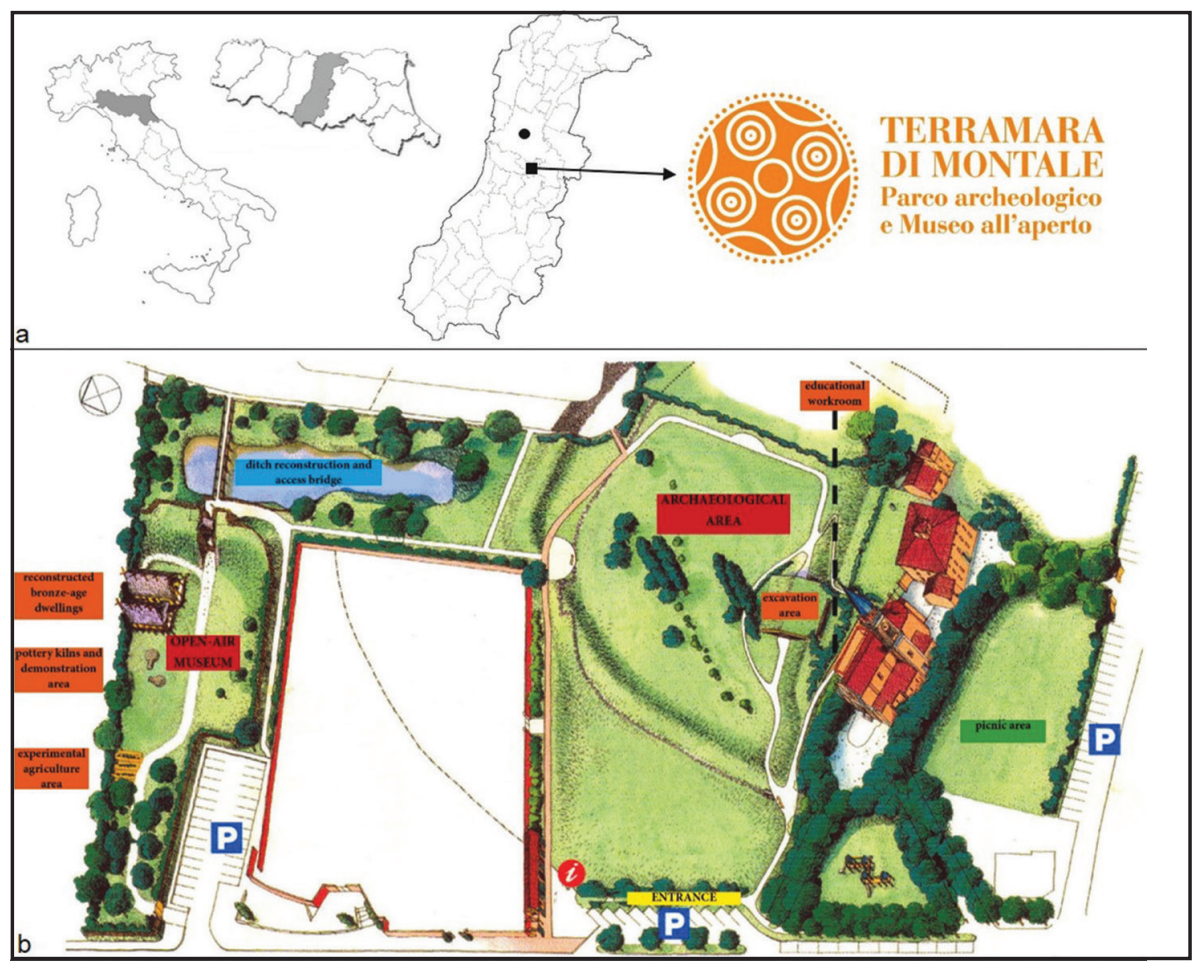

Figure 1. a) Location of the Terramara Park of Montale. b) Plan of the site and the openair museum of the Terramara Archaeological Park of Montale. 
between research and divulgation, through which the visitors get involved and become aware about scientific issues that are otherwise only for specialists. The scientific basis for the Park's realization was supplied by $19^{\text {th }}$ century archaeological excavation at Montale and, above all, by the data obtained from the excavations carried out between 1996 and 2001 that led to the discovery of the stratigraphic sequence and structural aspects. The ancient dwellings, which are only partly preserved, occupy the Park's southern sector where the excavation area has been protected with a structure that is today a museum space with plaster casts of the terramara stratigraphy and layers. Next to the archaeological area, in the Park's northern sector, the open-air museum has been set-up. Here a full-scale sector of the terramara village has been reconstructed based on the supply of data from the excavations (Cardarelli et al. 2015a) (Figure 1b).

The rich archaeological record has provided much information about the daily life of people living in the site area (Cardarelli 2009). By the beginning of the $20^{\text {th }}$ century, natural sciences were becoming increasingly important in the comprehension of archaeological sites (Wilkinson, Stevens 2008). In fact, for several sites the study of botanical remains was crucial to obtaining information about human life in the past (Day 2013), as was the case of the Montale terramara (Accorsi et al. 2009; Mercuri et al. 2006a; 2006b; 2012).

The amount and quality of archaeobotanical analyses carried out in this site allowed useful information to be obtained for the achievement of different proposals for the activities involving kids and adults. These activities are intended to explain and help understand the human-plantanimal relationships in the terramare communities (Bosi et al. 2013a; Bosi et al. 2013b)

. This is real added value, especially considering that there are no written records from protohistory: information is available only through the different types of materials recovered from archaeological excavations and their analysis.

A fruitful cooperation between the Laboratory of Palynology and Archaeobotany of the University of Modena and Reggio Emilia and Civic Museum of Archaeology and Ethnology of Modena has commenced since the planning phase of the Park, and still continues. Hopefully, this successful cooperation can serve as an example for other national and international archaeological open-air museums and parks.

\section{A visit to the Park}

The Terramara Archaeological Park of Montale offers to visitors the opportunity to experience the reconstruction of a section of the terramara, the Bronze Age villages surrounded by trenches and embankments that largely occupied the central Po Valley between the $17^{\text {th }}$ and mid- $12^{\text {th }}$ centuries BC. Built entirely of wood, clay and plant fibres, these ancient settlements left such faint traces that only the trained eye of an archaeologist could detect and interpret them. The reconstruction in Montale is based on a solid scientific premise: the existence at the same site of a partially conserved terramara, where excavations conducted by the Archaeological Museum of Modena have uncovered the remains of the village's fortification and dwellings, as well as plentiful artefacts. The open-air museum's reconstructions now sit alongside the site of the original settlement, offering to the visitors a unique experience in which some level of comprehension of the excavation is facilitated by the evidence of the reconstructions.

Some educational programmes are especially conceived for school groups, where the evocative side of the reconstruction is combined with the scientific aspects of the archaeological excavations. In fact, the visit retraces the steps of the archaeologists' work: young students are engaged in tracing back the history of the ancient settlement starting from the archaeological records, thus becoming aware of the methods implied in the archaeological fieldwork, from excavation to analysis and interpretation.

The visit starts in the area originally occupied by the Bronze Age settlement (Pulini, Zanasi 2009) (Figure 1b):

1. The excavation area is contained within a covered shelter. The vertical section of the dig is displayed on the back wall, where layers corresponding to the various phases of village life between 1600 and 1250 B.C. are highlighted. The traces of two large dwellings, dating back to the most ancient phases of the settlement, can be observed on the surface. Explanatory panels illustrate the excavation and the types of materials recovered and provide information about the environment and the productive activities of the terramare.

After the presentation of the excavation's site, schoolchildren are engaged in an archaeological excavation in a purpose-built recreated ditch. Each student analyses a particular aspect of the excavation and selects one record from the excavation for further examination. The variety of objects that are handled by the children are representative of the main types of material found during the excavations of the terramare: ceramics, bronze, horn, stone, wood, animal bone and seeds (recovered through sifting).

2. The next step of the archaeological investigation's programme takes place in the nearby laboratory. The educational laboratory presents panels displaying the main types of finds, reconstructions, comparative materials, as well as audio-visuals, microscopes, magnifying glasses and measuring instruments. In this well-equipped space, children fill in data sheets for the different finds brought to light from the excavation, be it a pottery shard, a charred seed, or a bronze piece or the jawbone of an animal, using the range of special instruments to help them.

3. After training on the research methods, schoolchildren reach the reconstructed dwellings to cross-check the data they have collected with the reconstructed setting of the open-air museum. The Open-Air Museum features life-size reconstructions of part of the village, 
including the ditch, the defensive earthworks, a substantial fortified entrance and two large true to life houses furnished with pottery, utensils, arms and clothes, all of which faithfully reproduce the originals of 3,500 years ago. The two houses were reconstructed on the basis of the two most ancient strata of the terramara (phase I and II) dated to 1600 and 1450 BC respectively.

This visit as described is substantially the same one followed by the general public composed of families, students of high schools or universities, museum's professionals, archaeologists or enthusiasts.

During open days (Sundays and Holidays of April, May, June, September and October), archaeologists and experts from among the staff offer visitors guided tours accompanied by demonstrations of various handcraft techniques or experimental archaeology and hands-on children laboratories, following the two seasonal programmes (spring and autumn) of events.

\section{Archaeobotany for the Terramara Park}

Archaeobotanical research has been crucial for implementing the Park's activities and organization. The green area of the Open-Air Museum has been planned according to palynological, carpological and xylo-anthracological analyses. Almost all the "exotic" tree species standing in the area have been replaced by plants identified by the archaeobotanical investigations. However, the larger and older trees have not been felled, because they too are considered to carry with them the history of the place.

Along with trees and shrubs belonging to the SubBoreal mixed oak-wood of the Po plain (e.g. broadleaved oak, hornbeam, elm, maple, ash, linden or lime tree, and blackthorn), also walnut, European yew, willow and vine have been planted. Moreover, aquatic species (e.g. reed, rushes, sedges, cattails and water lilies) identified by the pollen analyses have been placed around the reconstruction of the village ditch (Cardarelli 2009).

Furthermore, the Montale archaeobotanical record has also been of key importance for understanding the different interactions between plants and man throughout the history of the settlement.

\subsection{Wooden artefacts}

As suggested by the pollen spectra, the landscape before the founding of the settlement was characterised by a denselyforested area. A sudden decrease in trees then occurred at the onset of the terramara. The inhabitants of the terramara collected trees for building the wooden fences and houses of the settlement (Accorsi et al. 2009). Moreover, xyloanthracological analyses have suggested that they mainly used oak for the piles supporting the framework and roofs, less hard wood for the walls (e.g. branches of hazelnut and bundles of reed) and tools (e.g. maple, hazelnut, pedunculate oak, etc.), and also different species for fuel (e.g. oak, hornbeam, maple, etc.) These people thus appeared to have a good knowledge of the technological qualities of wood (Mercuri et al. 2006a; Cardarelli et al. 2009). Such archaeobotanical information was essential for an accurate reconstruction of houses and fortifications within the archaeological park.

\subsection{Agriculture}

The sudden decrease of forest at the onset of the terramara coincides with a rapid increase of cereals in the pollen spectra, thus suggesting that deforestation was practised to obtain cultivable land. Cereals are abundant also in the carpological record, confirming that their economy was based on cereal (especially barley and forms of wheat) cultivation. In addition, the high concentration of Cichorioideae pollen (belonging to the Compositae [daisy] family) testifies that in the area of influence of the terramara, pastures were used for grazing domestic animals. The comparison between cereal and Cichorioideae pollen curves and micro-charcoal concentrations suggests the adoption of several agricultural practices on the site: cultivation/pasture rotation, crop rotation, and the possible use of fire to burn arable stubbles and create fertile fields (Mercuri et al. 2006b).

\subsection{Vegetal diet}

At Montale, as in other sites of the same period, the large quantity of caryopses - most of them recovered from a storage location destroyed by a fire - documented that during the Bronze Age cereals were the staple diet in the Po plain. In addition, some legumes (field beans, lentils and vetches), probably cultivated close to their houses, were other plant food consumed by the inhabitants of the terramara. An additional important source of food was represented by wild woody plants, such as dogwood, hazelnut, blackthorn, pear and apple tree (Accorsi et al. 2009).

An interesting datum is represented by the cornelian cherry and grape values documented by the carpological record in the last phases of the settlement. Cornelian cherry stones are always more abundant than grape pips, except at the end of the life of the terramara, when grape pips dominate. This inversion could suggest a cultural shift in alcoholic drinks from cornelian cherry wine to grape wine (Accorsi et al. 2009; Mercuri et al. 2006a; Bandini Mazzanti et al. 2005), as already suggested by Castelletti et al. (2001) for northern Italy at the transition from Bronze Age to Iron Age.

Recent morphobiometrical analyses have shown that about $76 \%$ of grape pips recorded at Montale belong to a cultivated grape group (Cardarelli et al. 2015b). Further ongoing research will confirm or deny the hypothesis of grape cultivation during the Bronze Age, not only for the south but also for the north of Italy.

\subsection{Fibre and dye crops}

As in almost all archaeobotanical records from terramare, there is no direct evidence of textile remains. However, the intensive production of yarn and fabric is testified by the several spindle whorls and loom weights recovered by archaeologists (Pulini, Righi 2009). 
In the Open-Air Museum, a parcel of land has been devoted to the cultivation of flax, although this plant has not been documented by the archaeobotanical analyses. However, the recovery of flax seeds from other Bronze Age sites would suggest that flax was employed for weaving along with wool (Cardarelli et al. 2009), rather than hemp (attested by the Montale pollen record - Mercuri et al. 2006a) that was more suitable for rope production. Although, it cannot be excluded the use of wild plants for yarn, such as nettle, now recognised as an important textile plant in Europe during the Bronze Age (Bergfjord et al. 2012), and documented at Montale within the anthropogenic pollen indicators (Mercuri et al. 2012).

Plants like woad (Isatis tinctoria - for blue) and madder (Rubia tinctorum - for red), available in the village surroundings, were probably employed for yarn dyeing by

the inhabitants of the terramara. Brown could have been achieved from barks rich in tannins (e.g. oaks or walnuts), while other colours - from yellow to violet - could have been obtained by small fruits (e.g. cornelian cherries, elderberry and vine grapes, all of them documented by the archaeobotanical remains - Mercuri et al. 2006a).

Along with wool and flax, probably used for yarn for clothes, several plants witnessed by the archaeobotanical evidence (e.g. hazelnut, viburnum, ash and willow trees, grasses and rushes) could have been useful for making ropes, nets and straw (Pulini, Righi 2009).

\section{The archaeobotanical data and their museum display}

Figure 2. a) The landscape around Montale before the founding of the Bronze Age village. b) Deforestation during the early stage of the village.

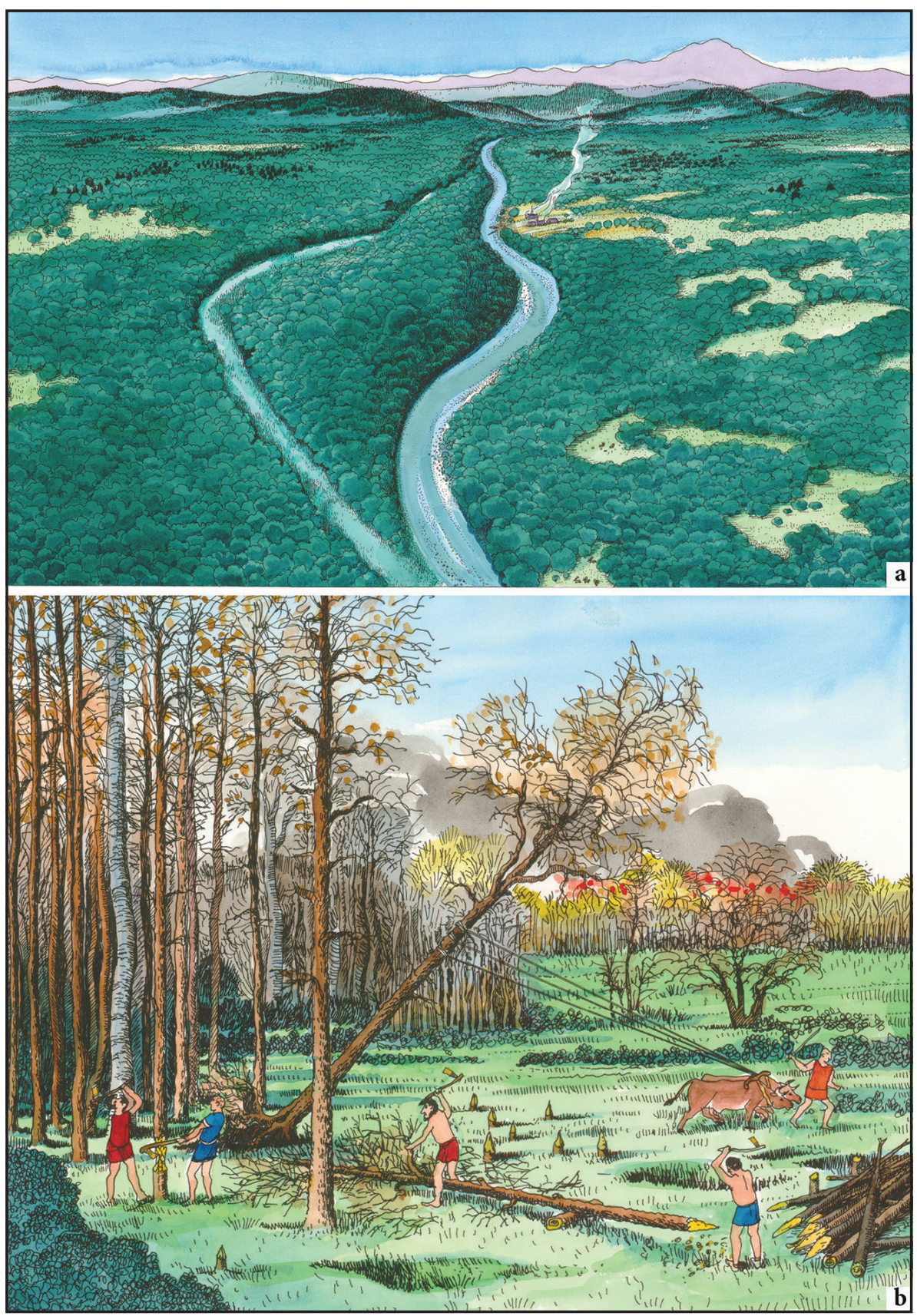


The total number of open day visitors (Sundays and Holidays of April, May, June, September and October) has reached nearly 120,000 over the last 12 years (representing 22 annual open days of which 2 or 3 per year were dedicated to archaeobotanical topics).

Museum and teaching materials, produced thanks to the archaeobotanical analyses, have been placed in all parts of the Park. On the discovery trail, several graphical reconstructions of the human impact on the natural environment of the site (Figures 2a, 2b) tell the visitors why the terramare civilization is considered responsible for the first strong anthropic change of the landscape in the Po plain (Accorsi et al. 2009). Visitors are guided by fascinating reconstruction drawings for an understanding of the landscape around the settlement (Figure 3). Other materials have been employed in specific areas of the Park:

1. Excavation area (Figure 4a): a) according to the pollen analyses, large simplified graphs (linked to an illustrated archaeological stratigraphy) have been drawn in order to show both the forest cover fluctuations and cultivation and pasture variations through time (Figures 5a, 5b). Following the carpological data, crops have been quantified for the site (Figure 5c), and dogwood and grape oscillations evaluated over time (see above: "Vegetal diet") (Figure 5d); b) plant materials (seed/fruits and wood/ charcoals) - recovered by kids through sieving - have been introduced in the "simulate dig" activity (Figures $4 \mathrm{~b}, 4 \mathrm{c})$; c) this is the place where temporary thematic exhibitions are displayed connected to archaeological, archaeobotanical and archaeozoological results, concerning the natural and anthropic environment, agriculture, breeding and alimentation.
2. Educational workroom (Figure 6a): a) original archaeobotanical remains suitable for the optical microscope (pollen) and stereomicroscopical (seeds/ fruits and woods/charcoals) observations (Figure 6b); b) a panel which helps kids to link archaeobotanical remains to their plant of origin (Figure 6c); c) botanical elements coming from the archaeobotanical research have been represented in different didactic sheets used by students, especially in the section "Botanical remains" (Zanasi 2014b) (Figure 6d). d) resin threedimensional scale models $(\times 200)$ of the main pollen types of cereals and trees identified at Montale through the archaeobotanical analyses (Accorsi et al. 2003) (Figure 6e).

3. Open-Air Museum (Figure 7a): a) parcels of land, where cultivated crops observed in the archaeobotanical record (e.g. wheat, rye, millet, barley, field bean, lentil, chickling vetch and peas) should be seeded every year (Figure 7b) (Cardarelli et al. 2009); b) inside the huts, plant materials have been placed in different contexts (such as bowls and baskets) depending on the season, in order to point out their use in the daily life of the inhabitants of the Terramara (Figure 7c).

\section{Paleoethnobotany and dissemination activities}

During open days the Terramara Park of Montale offers to the general public events on the theme of Archaeobotany. Considering that children aged from 6 to 10 are the largest part of the public, the park uses educational activities linked to the natural sciences that involve methodologies not traditionally employed at school: games, simulations,

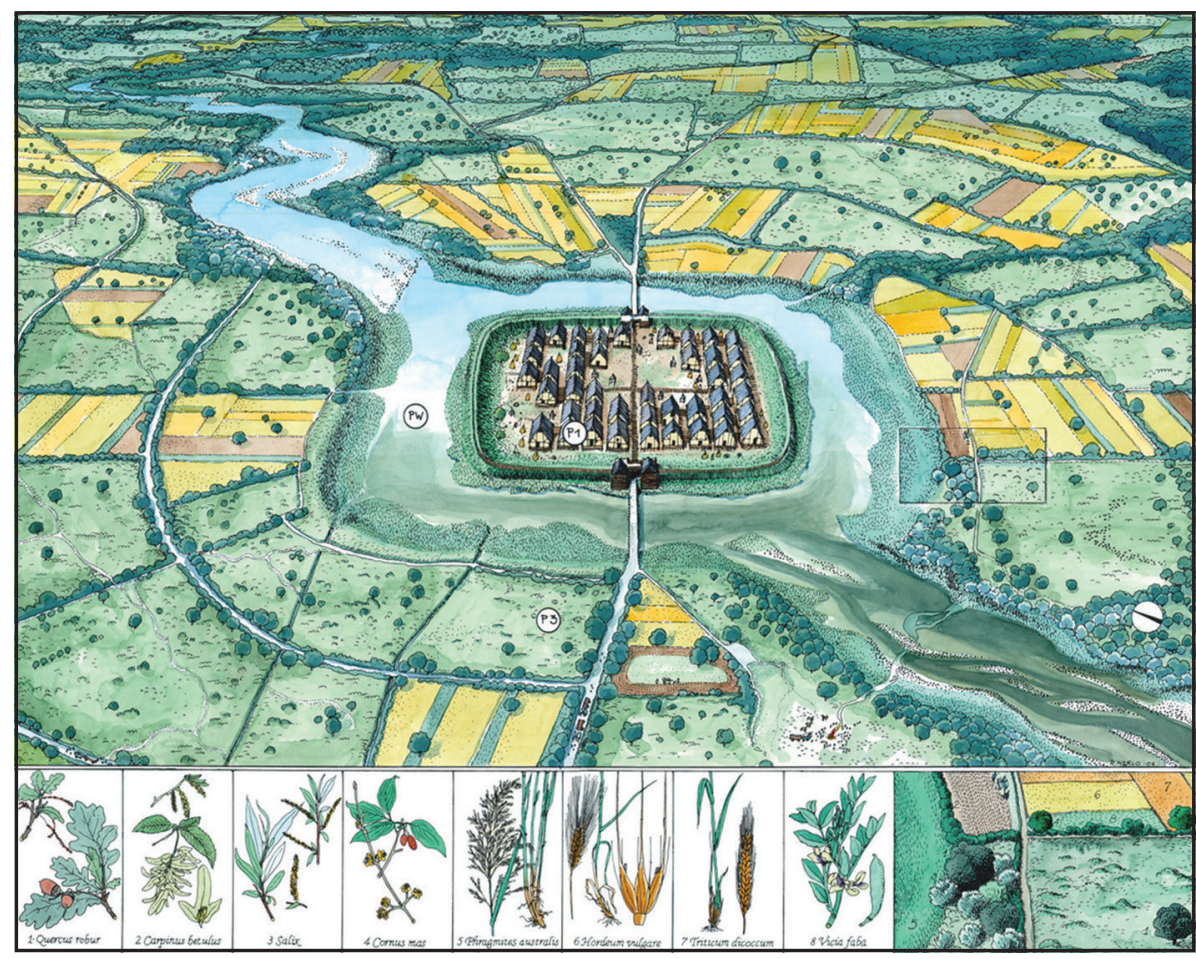

Figure 3. The village and its environment around 1500 B.C. with documented plant species. 
Figure 4. a) The archaeological area of the Terramara Park of Montale. b) The archaeological strata reconstructed for the "simulated dig". c) A child during the activity of excavation.
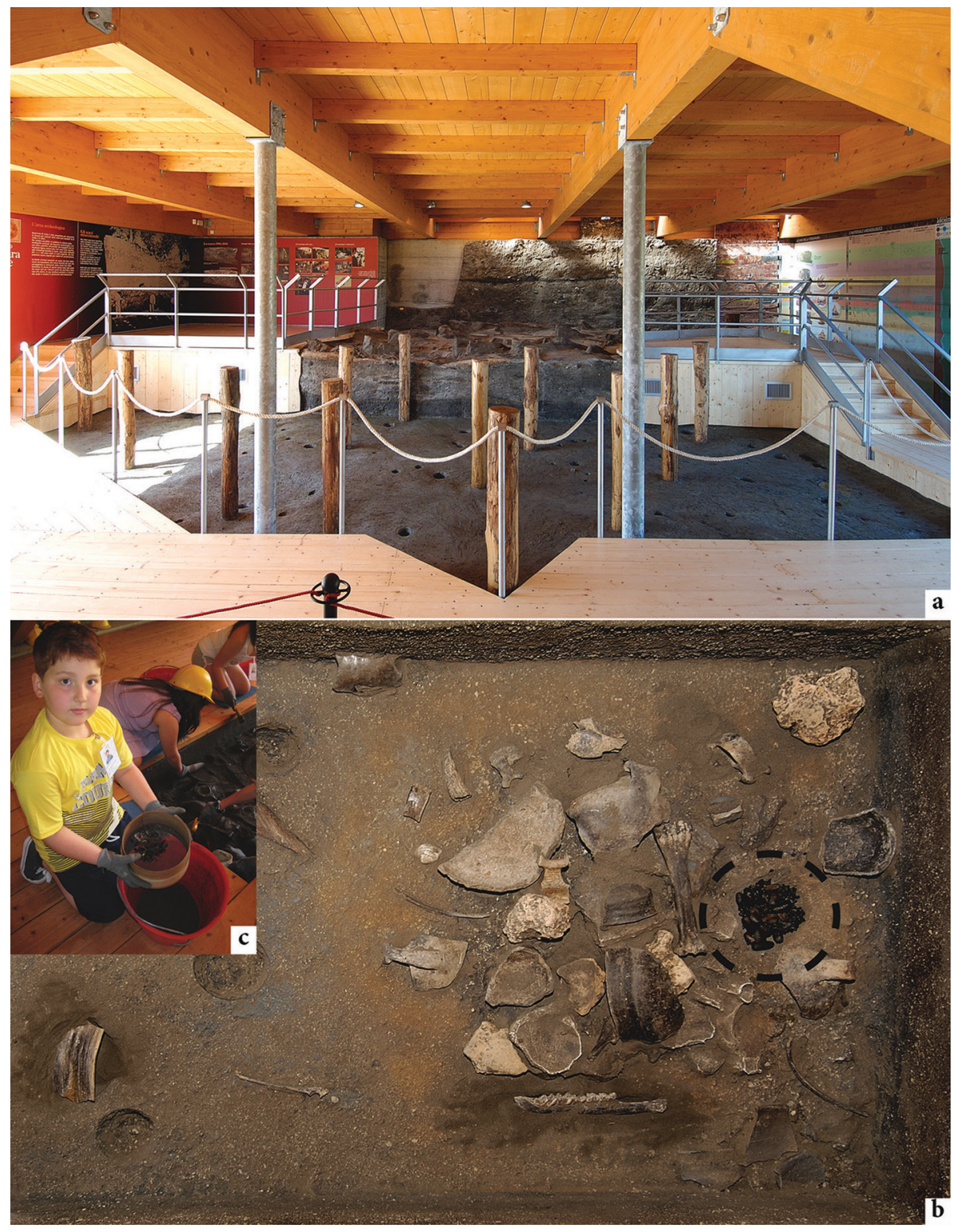

and exploration of the territory and collection (Maso 2010). According to Mortari (2009), the best experiences are the sensory ones, which yield significant changes in our ways of thinking and living.

Using the archaeobotanical data, it was possible to achieve different proposals for the Park educational workshops, activities and demonstrations to make the approach of visitors of all ages ( $\mathrm{K}=$ kids; $\mathrm{E}=$ everyone) more effective to the different ethnobotanical aspects of the site.

- The environment at the time of the terramaras (E) - Presentation of research aimed to reconstruct the environment in the past: pollen, pieces of charcoal and wood, seeds and fruits recovered in the archaeological excavations that has led to an understanding of the Po plain landscape during the Bronze Age (Figure 8a).

- Archaeobotany for kids (K) - Everybody joins in to sieve soils, collect, count and identify the seeds and fruits of cultivated plants or collected by the terramara people 3500 years ago (Figure $8 \mathrm{~b}$ ).
- The Terramara's Herbarium (K) - Learning to recognise some relevant wood species at Montale: alder, hornbeam, oak, ash, maple, hazelnut. Through the creation of a herbarium, all the possible uses of these trees/shrubs in the Bronze Age can be known (Figure 8c).

- Woodworking (E) - Demonstrations of different techniques used in woodworking of both structures and artefacts, from the cutting of stakes through to the insertion of wedges beaten in with wooden hammers, to the creation of interlocking systems ("wood joints") by means of axes and bronze chisels (Figure 8d).

- Building without bricks: the houses of the terramara (K) - A laboratory for children to learn how reeds, grasses and branches were used for weaving and the plastering of walls of houses (Figure 8e).

- The bread cycle (E) - A day devoted to the bread production cycle: from the wheat harvest, threshing and grinding, to bread preparation and tasting. The 


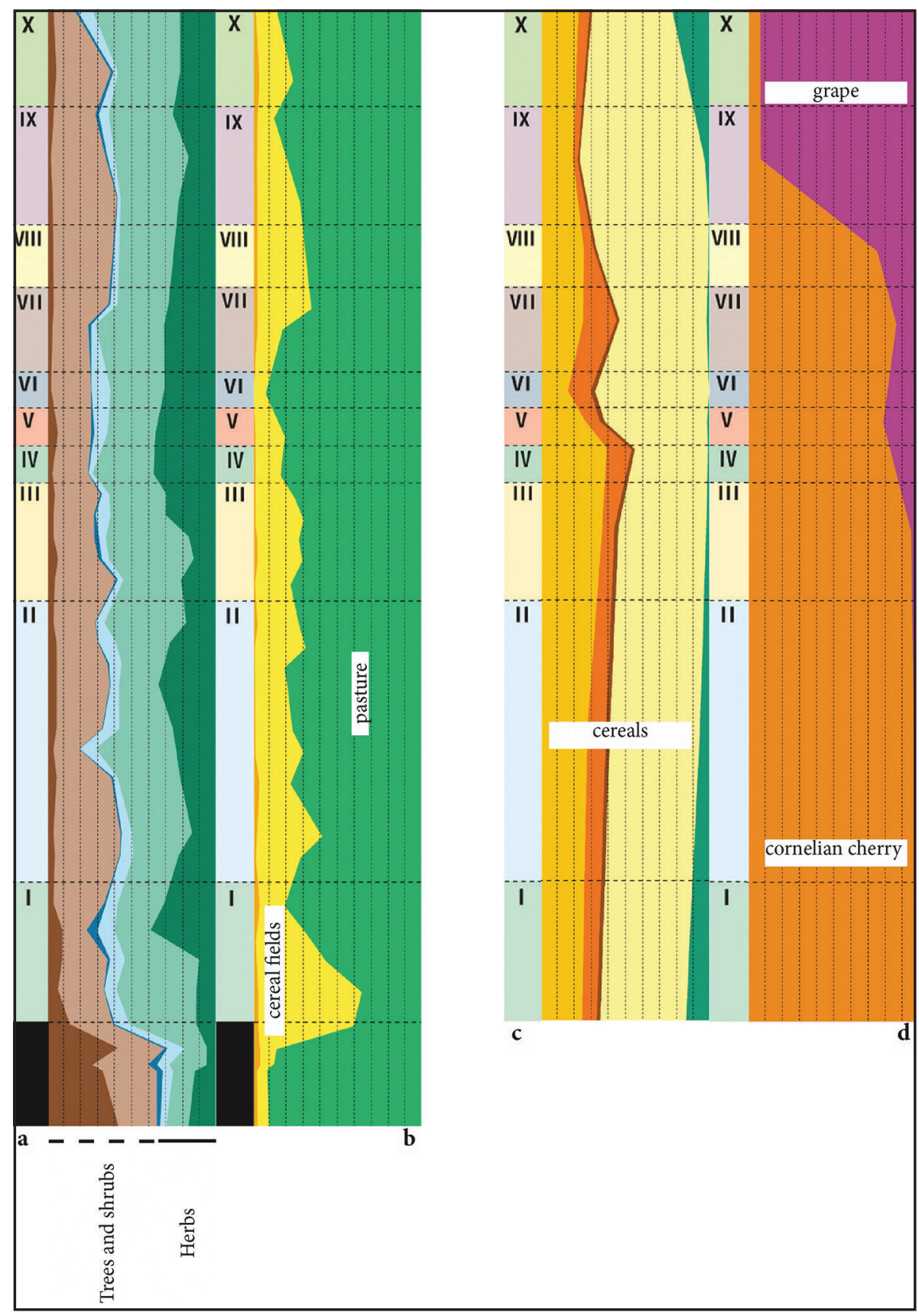

Figure 5. Simplified pollen, seeds and fruits diagrams. Percentages divided by phases of the village life.

different phases of this chain are explained using instruments philologically reproduced from the original ones recovered from the excavations: bronze sickles, millstones, pottery, wooden breadboards and spoons. The bread is cooked over hot coals in a clay kiln (Figure 8f).

- Archaeology of food and flavours (E) - Exhibition showing archaeological finds and panels, activities and tasting on the subject of food in the terramare, aimed to provide information on how and what the people of the Po plain used to eat during the Bronze Age (Figure 8g).

- Archaeology of wine and other beverages (E) The history of wine and grapes and other fermented beverages from the Bronze Age to the present day through small conferences and activities (Figure 8h).
- Weaving of plant fibres and marsh grasses (E) Demonstration on the techniques employed during the Bronze Age for baskets, ropes, nets and mats woven by using the plant fibres then available to the Terramara inhabitants (Figure 8i) (in collaboration with "Ethnographic Centre Marshy Civilization", Villanova di Bagnacavallo - Ravenna, Italy).

- One thread pulls another $(\mathrm{K})$ - After the observation of the functioning of two looms reconstructed in the houses of the Open-Air Museum, visitors can try to make bracelets of flax by using Bronze Age techniques (Figure 8j).

- The park in blue $(\mathrm{K})$ - Blue as in flax flowers and the colour obtained from woad, the dye plant recently rediscovered. By the use of woad and also madder 
Figure 6. a) Educational workroom. b) Looking at archaeobotanical finds under the microscope. c) Panel with archaeobotanical remains and the plants of the origin. d) Completing data sheets concerning archaeobotanical remains. e) Samples of different cereals and resinous three-dimensional scale models of the main pollen types of cereals and trees identified in Montale Terramara.

Figure 7. a) Two life-size reconstructed houses in the open air museum. b) Plots of land with cultivated herbs observed in the archaeobotanical record. c) House interior with plant materials placed in different contexts.
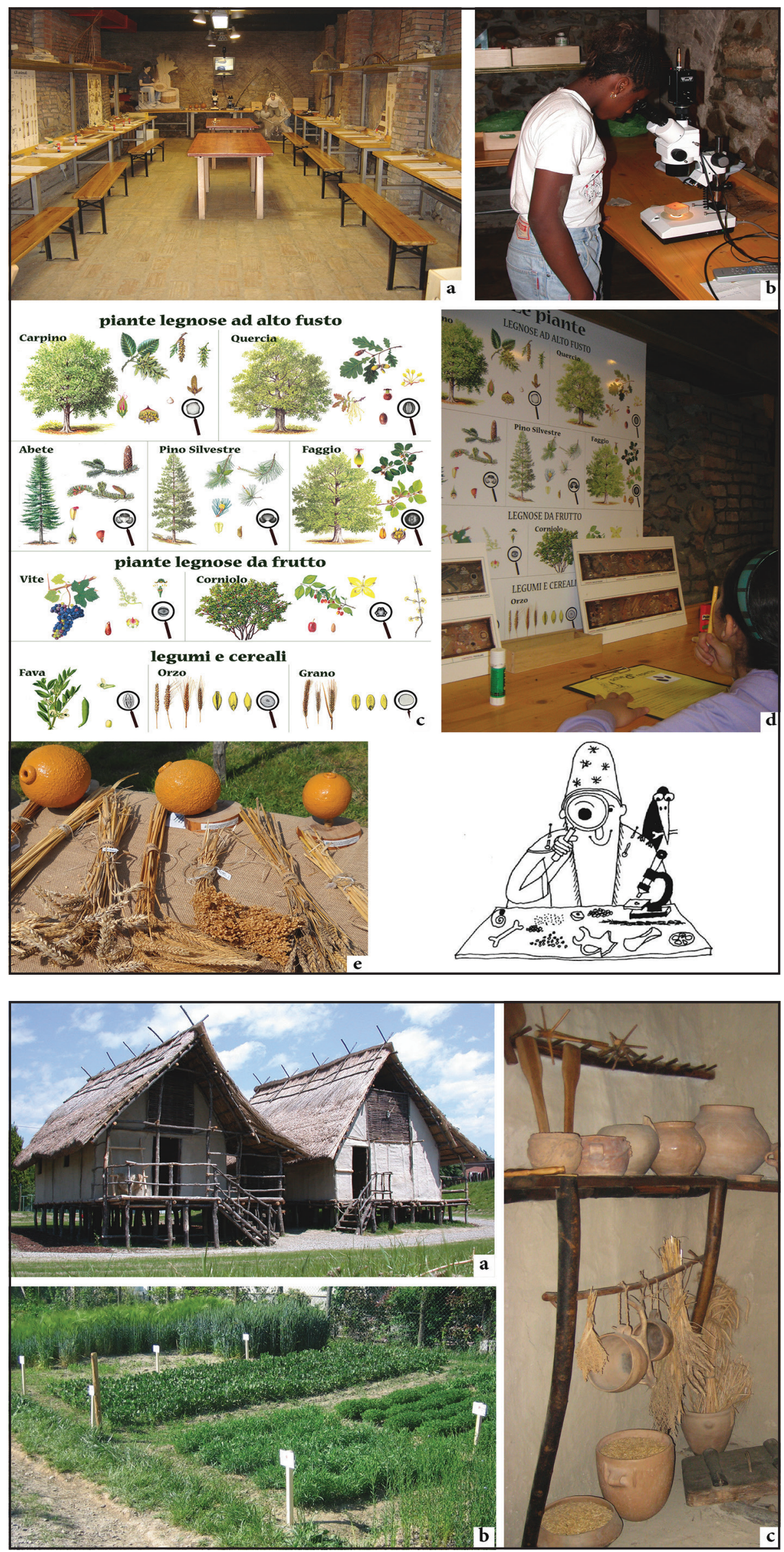


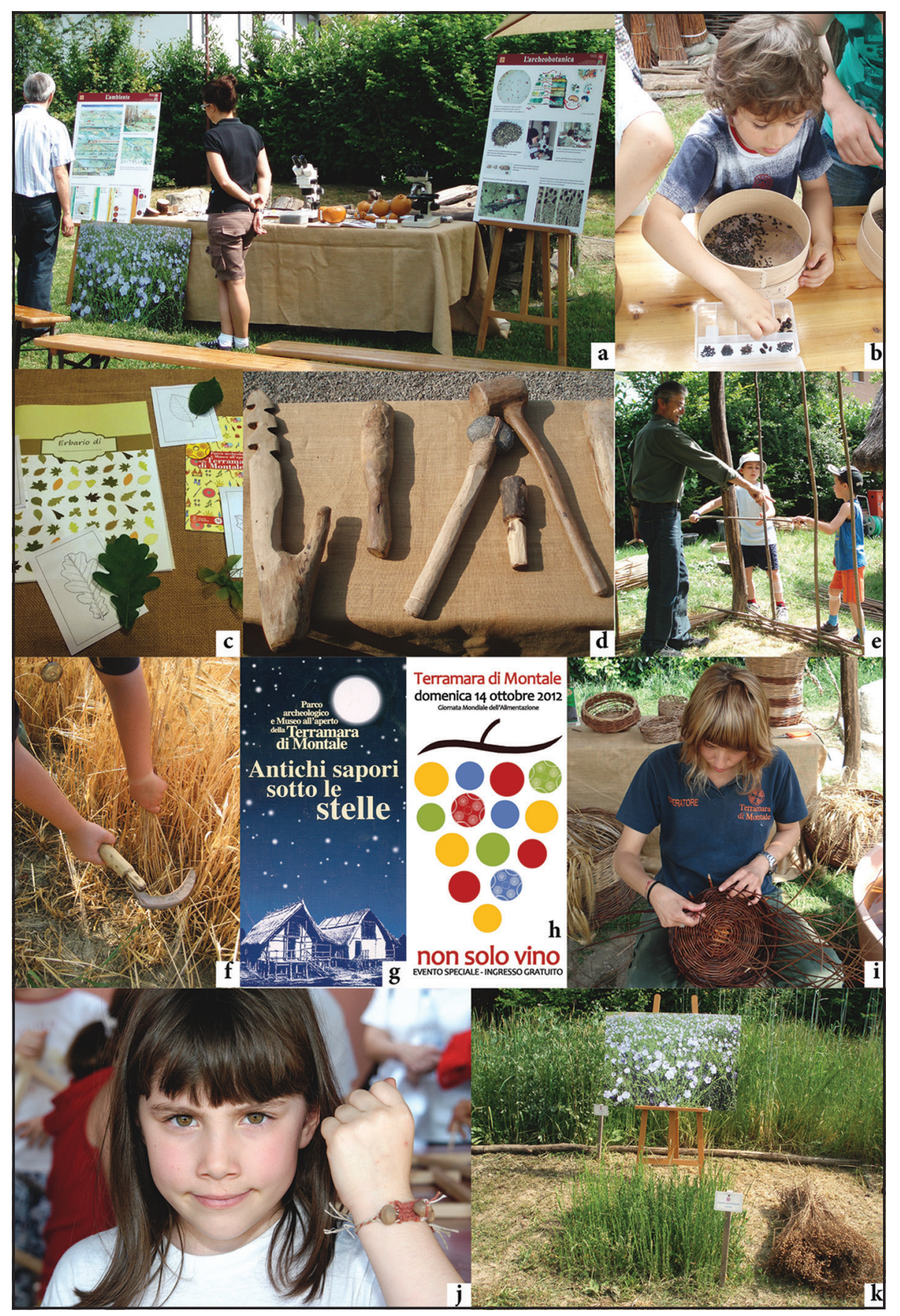

Figure 8. Dissemination activities for the visitors: a) The environment at the time of the terramaras. b) Archaeobotany for kids. c) The Terramara's Herbarium. d) Woodworking. e) Building without bricks: the houses of the terramara. f) The bread cycle. g) Archaeology of food and flavours. h) Archaeology of wine and other beverages. i) Weaving of plant fibers and marsh grasses. j) One thread pulls another. k) The park in blue.

and weld (Reseda luteola), it is possible to experiment with the natural colour of linen textiles (Figure 8k) (with advice of "Museum of Natural Colours "Delio Bischi"”, Lamoli - Pesaro-Urbino, Italy).

\section{Conclusions}

The study of prehistoric sites, as in the case of the Terramara of Montale, must invest a great deal in the interpretation of every type of record, so that our knowledge about human history in all its facets can be expanded.

The potential of botany in the archaeological field is very broad and yet to be discovered in all its aspects for obtaining new information on the relationship between humans and the environment and plants, both spontaneous and cultivated (e.g. Bandini Mazzanti, Bosi 2013; Day 2013).

The archaeobotanical study of necropolis and sacred areas could also provide new interesting developments in this field (e.g. Montecchi et al. 2014).

The Terramara Archaeological Park of Montale represents a perfect place to experiment how this information can be made accessible to all types of audience.

The various elements of the park, developed thanks to archaeobotanical analyses, are appreciated and used by many visitors, often independently; however, of prime 
importance is the presence of illustrative panels, simple and straightforward, but graphically very effective. These elements are also used for educational guided tours, as environmental reconstruction and the relationship of humans with natural resources are fundamental to understand the terramare period.

Over the years, more than ten educational workshops and demonstrations of different targets have been planned and proposed, received the appreciation of the audience and has enabled the use of several techniques, including experimental archaeology, in order to maximise the involvement of participants.

This alliance between archaeology and botany, realized in different ways in the Terramara Archaeological Park of Montale, has turned out to be successful and showed how scientific research can and must be used to make archaeological contexts more accessible and understandable.

\section{Acknowledgments}

Many thanks to all the people who, together with us, have investigated archaeology and archaeobotany of Montale Terramara, e.g. Carla Alberta Accorsi, Francesco Benassi, Andrea Cardarelli, Ilaria Cassetta, Claudio Cavazzuti, Donato Labate, Antenore Manicardi, Marco Marchesini, Marta Mazzanti, Anna Maria Mercuri, Riccardo Merlo, Gianluca Pellacani, Ilaria Pulini, Paola Torri and Giuliana Trevisan.

All the drawings were made by the architect Riccardo Merlo; photographs appear courtesy of the Civic Museum of Archaeology and Ethnology of Modena.

\section{References}

ACCORSI, C. A., BANDINI MAZZANTI, M., BARBERINI, E., BOSI, G., GIANAROLI, C., MERCURI, A. M., TREVISAN GRANDI, G. 2003: La collezione museale archeobotanica della Terramara di Montale (Bronzo Medio - Bronzo Recente). Sezione I - I modelli di tipi pollinici di cereali. In: Abstracts Book Convegno A.i.Ar. "Biologia e Beni Culturali”, Como, Settembre 22-23. Comune di Como.

ACCORSI, C. A., BANDINI MAZZANTI, M., BOSI, G., MARCHESINI, M., MERCURI, A. M., TREVISAN GRANDI, G. 2009: The archaeobotanical analysis. In: Cardarelli A. (Ed.): Guide to the Archaeological Park and Open-Air Museum Terramara Montale. Museo Civico Archeologico Etnologico, Modena, 64-67.

BANDINI MAZZANTI, M., BOSI, G., RINALDI, R. 2005: Morfobiometria degli endocarpi di Cornus mas L. nell'Età del Bronzo e nel Periodo Romano in Emilia. Informatore Botanico Italiano 37 (1-B), 890-891.

BANDINI MAZZANTI, M., BOSI, G. 2013: Studi archeobotanici nella ricerca etnobotanica. In: Caneva, G., Pieroni A., Guarrera P. M. (Eds.): Etnobotanica. Conservazione di un patrimonio culturale come risorsa per uno sviluppo sostenibile. Edipuglia, Bari, 29-34.

BERGFJORD, C., MANNERING, U., FREI, K. M., GLEBA, M., SCHARFF, A. B., SKALS, I., HEINEMEIER, J., NOSCH, M. L., HOLST, B. 2012: Nettle as a distinct Bronze Age textile plant. Scientific Reports 2 (664), DOI:10.1038/srep00664.

BERNABÒ BREA, M., CARDARELLI, A., CREMASCHI, M. (Eds.) 1997: Le Terramare: la più antica civiltà padana. Electa, Milano. BOSI, G., MERCURI, A.M., BANDINI MAZZANTI, M. 2013a: Parchi archeologici ed etnobotanica. In: Caneva, G., Pieroni, A., Guarrera, P. M. (Eds.): Etnobotanica. Conservazione di un patrimonio culturale come risorsa per uno sviluppo sostenibile. Edipuglia, Bari, 2019-213.

BOSI, G., FLORENZANO, A., RINALDI, R., BARBIERI, G., FRAULINI, E., ZANASI, C. 2013b: Archaeobotany and the archaeological park "Terramara Montale" (Northern Italy): a winner joint-venture. In: Abstracts Book $16^{\text {th }}$ Conference International Work Group for Palaeoethnobotany, Thessaloniki, June 17-21. Aristotle University of Thessaloniki.

CARDARELLI, A. (Ed.) 2009: Guide to the Archaeological Park and Open-Air Museum Terramara Montale. Museo Civico Archeologico Etnologico, Modena.

CARDARELLI, A., BENASSI, F., PELLACANI, G. 2009: The dwellings. In: Cardarelli, A. (Ed.): Guide to the Archaeological Park and Open-Air Museum Terramara Montale. Museo Civico Archeologico Etnologico, Modena, 75-85.

CARDARELLI, A., PULINI, I., ZANASI, C. (Eds.) 2015a: Montale the Terramara Lives. EXARC Journal 4/2015 (2).

CARDARELLI, A., BOSI, G., RINALDI, R., UCCHESU, M., BACCHETTA, G. 2015b: Vino o non vino? Nuovi dati sui vinaccioli della Terramara di Montale (Modena) tra la fine della media età del Bronzo e il Bronzo recente. In: Abstract on-line 50 ma Riunione IIPP "Preistoria del cibo. L'alimentazione nella preistoria e nella protostoria" Roma, Ottobre 5-9.

CASTELLETTI, L., CASTIGLIONI, E., ROTTOLI, M. 2001: L'agricoltura dell'Italia settentrionale dal Neolitico al Medioevo. In: Failla, O., Forni, G. (Eds.): Le piante coltivate e la loro storia. FrancoAngeli, Torino, 33-84.

DAY, J. 2013: Botany meets archaeology: people and plants in the past. Journal of Experimental Botany 64 (S1), 1-12.

DE GROSSI MAZZORINI, J., RUGGINI, C. 2009: The archaeozoological analysis. In: Cardarelli, A. (Ed.): Guide to the Archaeological Park and Open-Air Museum Terramara Montale. Museo Civico Archeologico Etnologico, Modena, 68-69.

DYER, A. 2007: Inspiration, Enchantment and a Sense of Wonder ... Can a New Paradigm in Education Bring Nature and Culture Together Again? International Journal of Heritage Studies 13 (4-5), 393-404.

HOFFMAN, T.L., KWAS, M.L., SILVERMAN, H. 2002: Heritage Tourism and Public Archaeology. The SAA Archaeological Record, 30-32.

MASO, A. 2010: Ecologia in città. Giochi per educare alla sostenibilità. La Meridiana, Molfetta.

MERCURI, A. M., ACCORSI, C. A., BANDINI MAZZANTI, M., BOSI, G., CARDARELLI, A., LABATE, D., MARCHESINI, M., TREVISAN GRANDI, G. 2006a: Economy and environment of Bronze Age settlements - Terramaras - in the Po Plain (Northern Italy): First results of the archaeobotanical research at the Terramara di Montale. Vegetation History and Archaeobotany 16, 43-60.

MERCURI, A. M., ACCORSI, C. A., BANDINI MAZZANTI, M., BOSI, G., TREVISAN GRANDI, G., CARDARELli, A., LABATE, D., MARCHESINI, M., OLMI, L., TORRI, P. 2006b: Cereal fields from the Middle-Recent Bronze Age, as found in the Terramara di Montale, in the Po Plain (Emilia Romagna, Northern Italy), based on pollen, seeds/ fruits and microcharcholas. In: Morel, J. P., Tresserras, J. J., Matamala, J. C. (Eds.): The Archaeology of crop fields and Gardens. Edipuglia, Bari, 251-270.

MERCURI, A. M., BANDINI MAZZANTI, M., TORRI, P., VIGLIOTTI, L., BOSI, G., FLORENZANO, A., OLMI, L., MASSAMBA N'SIALA, I. 2012: A marine/terrestrial integration for mid-late Holocene vegetation history and the development of the cultural landscape in the Po Valley as a result of human impact and climate chage. Vegetation History and Archaeobotany 21 (4-5), 353-372.

MONTECCHI, M. C., MERCURI, A. M., BOSI, G., FORLANI, L., RATTIGHIERI, E., ACCORSI, C. A. 2014: Il paesaggio vegetale della Necropoli di Casinalbo secondo la ricerca archeobotanica su polline e carbone. In: Cardarelli, A. (Ed.): La Necropoli della Terramara di Casinalbo. Grandi contesti e problemi della Protostoria italiana 15. All'Insegna del Giglio, Firenze, 783-793.

MONTARI, L. 2009: La ricerca per $i$ bambini. Mondadori Università, Milano.

PANOSA, M.I. 2012: Historical and Archaeological Heritage and its Social Transfer: Contributions and Challenges. International Journal of Humanities and Social Science 22/2, 146-151. 
PELILLO, A. (Ed.) 2009: Guide to the Archaeological Open Air Museums in Europe. Museo Civico Archeologico Etnologico, Modena.

PULINI, I., RIGHI, E. 2009: Planting, textiles and clothing. In: Cardarelli, A. (Ed.): Guide to the Archaeological Park and Open-Air Museum Terramara Montale. Museo Civico Archeologico Etnologico, Modena, $100-105$.

PULINI, I., ZANASI, C. 2009: Experiencing archaeology and Interpretation. The educational program at the Terramara of Montale (Italy). EuroRea. Journal for (Re)construction and Experiment in Archaeology 6/2009, $17-19$.

URTANE, M. 2000: Visible Archaeological Remains in Towns and Parks. International Journal of Heritage Studies 6/1, 77-82.
WILKINSON, K., STEVENS, C. 2008: Environmental archaeology: approaches, techniques and applications. Tempus Publishing, Stroud.

ZANASI, C. 2014a: Sperimentare per capire. Scuole e musei open-air alla luce dell'esperienza del Parco di Montale. Mundus - rivista di didattica della storia 7-8 (2011-2014), 73-81.

ZANASI, C. (Ed.) 2014b: Parco Archeologico e Museo all'aperto della Terramara di Montale (serie: I Musei per la Scuola). Artestampa, Modena.

ZANASI, C. 2015: New Challenges for Archaeological Open-Air Museums. Archaeological Open-Air Museums and the Dialogue with the Museum Community, OpenArch European project. 